\title{
EFEKTIVITAS COLABORATIVE LEARNING BERBANTUAN MEDIA SHORT CARD BERBASIS IT TERHADAP PEMAHAMAN KONSEP MATEMATIKA
}

\author{
Nuhyal Ulia \\ nuhyalulia@unissula.ac.id \\ Universitas Islam Sultan Agung Semarang
}

\begin{abstract}
ABSTRAK
Penelitian ini bertujuan untuk mengetahui karakteristik Collaborative Learning berbantuan media Short Card berbasis IT serta membandingkan mana yang lebih baik antara kemampuan pemahaman konsep matematika pada pembelajaran Collaborative Learning berbantuan media Short Card berbasis IT atau pembelajaran konvensional. Penelitian ini berjenis penelitian kuantitatif . Penelitian dilakukan di SDN Karangroto 01 Semarang. Adapun Teknik analisis data dalam penelitian ini meliputi normalitas data, uji homogenitas, uji kesamaan rata-rata dan uji banding. Berdasarkan hasil penelitian diperoleh pada uji hipotesis dihasilkan $t_{\text {hitung }}=13,20, \alpha=5 \%$ dengan $\mathrm{dk}=\left(n_{1}+n_{2}-2\right)=(48+48-2)=96, \mathrm{t}_{\text {tabel }}=1,99$ sehingga $\mathrm{t}_{\text {hitung }}>\mathrm{t}_{\text {tabel }}(13,20>1,99)$ artinya kemampuan pemahaman konsep pada pembelajaran Collaborative Learning berbantuan media Short Card berbasis IT lebih baik daripada pemahaman konsep matematika pada pembelajaran konvensional.
\end{abstract}

Kata Kunci: Collaborative Learning, Media Short Card berbasis IT, Kemampuan Pemahaman Konsep.

\section{PENDAHULUAN}

Pada Kurikulum 2013 yang merupakan kurikulum yang digunakan Indonesia saat ini mempunyai tujuan diantaranya agar dapat mempersiapkan siswasiswa Indonesia menjadi manusia Indonesia yang beriman, kreatif, inovatif dan mampu berkonstribusi pada kehidupan bermasyarakat. Untuk mewujudkan tujuan kurikulum tersebut, sekolah perlu untuk mengadakan inovasi pembelajaran yang tepat, yang mana guru bersama siswa dapat mempelajari materi dengan metode pembelajaran yang menarik dan sesuai dengan perkembangan zaman.
Sekolah Dasar (SD) merupakan satuan pendidikan sebagai bagian dari pendidikan dasar yang menyelenggarakan pendidikan selama enam tahun (Bafadal, 2003:3). Sebagai jenjang yang penting dan diperlukan maka sekolah dasar mempunyai peran utama dalam membentuk kepribadian serta membangun pengetahuan siswa. Pembelajaran di Sekolah Dasar sangat diharapkan dapat mengembangkan potensi siswa dalam membangun pengetahuannya.

Pada jenjang Sekolah Dasar (SD) pembelajaran yang diterapkan adalah pembelajaran tematik integratif. Hal ini 
mempunyai akibat yang positif yakni para siswa dapat mempelajari tema yang ada sebagai isu sentral yang didalamnya sudah terintegrasi berbagai mata pelajaran. Kurikulum yang saat ini sedang diterapkan tentunya sudah dibuat sedemikian rupa dan sesuai dengan kepribadian Bangsa Indonesia. Bangsa Indonesia sangat terkenal dengan keramahannya, gotong royong, toleransi, saling menghormati dan hidup rukun. Ini juga sesuai dengan Pancasila yang merupakan kepribadian bangsa Indonesia. dengan demikian kerja sama secara tidak langsung sudah diwariskan kepada anak cucu mereka.

Sikap kerjasama dalam pembelajaran mempunyai dampak positif terhadap siswa. Mereka dapat bertukar pikiran, saling membantu yang pada akhirnya mereka mempunyai solidaritas yang tinggi. Namun terkadang sikap kerjasama disalahgunakan seperti mencontoh pekerjaan temannya, bekerjasama dengan temanya pada saat tes atau ujian, bekerja sama dalam hal menyontek, yang mana semua itu sering terjadi hampir di setiap sekolah. Bahkan ironisnya jika ada siswa yang tidak menyontek atau bersikap jujur malah dipermasalahkan. Sebagaimana pemberitaan di Tribunews.com (2011) yang memberitakan Siami, melaporkan kepada pejabat pendidikan di Surabaya, provinsi Jawa Timur, bahwa guru anaknya yang berada di kelas 6, memberikan bocoran jawaban kepada para pelajar. Tapi tindakan itu justru menimbulkan kecaman dari masyarakat setempat. Ia dipaksa minta maaf secara terbuka setelah dikonfrontasi oleh kerumunan sekitar seratusan orang, dan ia bersama keluarganya akhirnya memutuskan pindah dari kawasan itu. Melihat kejadian tersebut, menjadi ironis sekali ketika melihat dunia pendidikan yang demikian.

Sudah saatnya sikap kerjasama yang sudah mereka miliki di arahkan pada hal-hal yang positif. Pembelajaran kolaboratif merupakan pembelajaran yang mengedepankan kerja sama dalam pelaksanaan pembelajaran. Siswa tidak hanya belajar secara kelompok, tetapi diarahkan pada inisiatif mereka sendiri dalam menggali pengetahuan. Dengan demikian, sangat diperlukan pembelajaran yang dapat mengakomodir karakter kerjasama yang ada pada siswa untuk dapat digunakan dan dikembangkan sedemikian rupa karena sejatinya sikap kerjasama yang sudah ada pada mereka mampu dan dapat diterapkan untuk mencapai tujuan pendidikan yang akan mereka capai.

\section{Collaborative learning atau yang}

dikenal dengan pembelajaran kolaboratif merupakan pembelajaran kelompok yang lebih menekankan pada inisiatif yang dibentuk sendiri bukan suatu hasil rekayasa orang lain untuk bekerja sama (Herlanti, Y:2011). Pembelajaran berkelompok yang sering kita dengar adalah pembelajaran kooperatif. Walaupun secara bahasa makna kolaboratif dan kooperatif adalah sama yakni bekerjasama. Namun dalam pembelajaran memiliki perbedaan. Menurut Jhonson dalam Herlanti,Y.(2011) pengetahuan yang lebih 
bermakna bagi siswa dapat dibina melalui pembelajaran kooperatif dapat membantu siswa untuk membina jika dibandingkan dengan pembelajaran yang dilakukan secara individu.

Media pembelajaran sangat diperlukan dalam pendidikan. Media yang menarik dan interaktif dapat membuat siswa antusias dalam pembelajaran sehingga materi yang disampaikan dapat terserap dengan baik. Salah satu contohnya adalah media short card atau kartu pendek. Media short card merupakan media yang cukup sederhana karena terdiri dari kartu-kartu pendek yang berisi tentang materi pembelajaran. adapun teknik penggunaan short card sesuai dengan strategi dan teknik guru dalam pembelajaran. Perkembangan teknologi juga berpengaruh terhadap dunia pendidikan. ICT (Information Computer technology) sebagai penggunaan komputer dan teknologi informasi sangat berdampak pada dunia pendidikan. Sebagai contoh pada proses PPDB sudal banyak yang menggunakan pendaftaran online. Ujian nasional yang berbasi komputer juga sedang digencarkan oleh pemerintah yakni sistem UNBK. Oleh karena itu, media short card dengan berbasis IT dapat dijadikan terobosan dalam pembelajaran. Adapun media short card nantinya tidak dibuat dengan kertas lagi melainkan akan dibuat dengan aplikasi komputer.

Berdasarkan hasil observasi pada SDN Karangroto 01 Semarang telah ditemukan beberapa permasalahan diantaranya pembelajaran yang digunakan di SDN Karangroto 01 masih konvensional, media yang digunakan masih sederhana belum menggunakan media yang berbasis komputer. Saat dilakukan wawancara terhadap guru kelas, beliau menyatakan bahwa hasil belajar siswa masih rendah terutama pada mata pelajaran matematika. Pembelajaran tematik integrative yang sedang dilakukan di kelas rendah masih belum maksimal. Terutama dalam kemampuan matematika siswa mempunyai kemampuan pemahaman konsep yang masih rendah, ini terlihat pada hasil pekerjaan matematika siswa yang mengerjakan perkalian dengan menjawab $2 \times 4=$ $2+2+2+2=8$. Ini merupakan salah satu contoh yang menunjukkan bahwa kemampuan siswa dalam memahami konsep pembelajaran matematika masih kurang. Dari pemahaman konsep dalam hal ini matematika yang masih salah dapat mempengaruhi kemampuan kognitif matematika sehingga prestasi belajar matematika menjadi rendah.

Dengan demikian di SDN Karangroto 01 sangat memerlukan inovasi pembelajaran yang dapat memacu sikap kerjasama yang sudah ada, yang menggunakan media dan mengikuti perkembangan teknologi dan akhirnya dapat efektif terhadap kemampuan pemahaman konsep matematika. Pembelajaran Colaborative Learning berbantuan media short card berbasis IT diharapkan dapat memberikan efek yang positif terhadap kemampuan pemahaman konsep dan lebih 
baik dari pembelajaran yang dilakukan secara konvensional.

Adapun penelitian ini mempunyai tujuan yaitu untuk mengetahui karakteristik pembelajaran model Colaborative Learning Berbantuan Media Short Card Berbasis IT dan untuk mengetahui apakah pemahaman konsep pada mata pelajaran matematika dengan Colaborative Learning Berbantuan Media Short Card Berbasis IT lebih baik dari pada pemahaman konsep matematika siswa pada pembelajaran yang dilakukan secara konvensional. Selain itu, manfaat dalam penelitian ini mempunyai manfaat bagi guru yaitu untuk menjadikan model Colaborative Learning Berbantuan Media Short Card Berbasis ICT sebagai inovasi pembelajaran yang dapat meningkatkan kemampuan pemahaman konsep matematika.

\section{METODE PENELITIAN}

Jenis Penelitian adalah penelitian eksperimen yaitu sebagai metode penelitian yang digunakan untuk mencari pengaruh perlakuan tertentu terhadap yang lain dalam kondisi yang terkendalikan. Desain penelitian ini menggunakan Pre-Experimental Desaigns yaitu Intact-Group Comparison. Pada desain penelitian ini terdapat satu kelompok yang dibagi dua bagian yaitu setengah kelompok untuk eksperimen (yang diberi perlakuan) dan setengahnya untuk kelompok kontrol (yang tidak diberi perlakuan) (Sugiyono, 2015:76).
Penelitian ini dilaksanakan di SDN Karangroto 01 Semarang. Sebagai Populasi adalah siswa kelas IV SDN Karangroto 01 Semarang. Teknik sampling pada penelitian ini menggunakan Simple random sampling. Adapun populasi dibagi-bagi menjadi beberapa kelas atau kelompok. Akan terpilih dua kelas atau kelompok yang homogen berdasarkan pertimbangan bahwa kedudukan siswa dalam kelas diterapkan secara acak tanpa melihat ranking nilai dan diajar oleh guru yang sama.

Pada penelitian ini, populasi dibagi menjadi beberapa kelas yaitu (1) Kelompok eksperimen yang mana pada kelompok ini diberikan suatu treatment atau perlakuan, yaitu model pembelajaran Collaborative Learning berbantuan media Short Card berbasis IT dan (2) Kelompok kontrol tidak diberikan treatment atau perlakuan apapun, pembelajaran menggunakan model yang biasa dilakukan yaitu dengan menggunakan model pembelajaran konvensional. Teknik pengumpulan data menggunakan teknik tes dan teknik nontes yang meliputi observasi, wawancara dan dokumentasi.

Sedangkan instrument penelitian ini meliputi lembar tes kemampuan pemahaman konsep, lembar observasi, pedoman wawancara dan lembar studi dokumentasi. Bentuk tes untuk pengambilan data penelitian adalah tes tertulis yang dimaksudkan untuk memperoleh data kognitif siswa pada kelompok eksperimen dan kelompok kontrol mata pelajaran Matematika yang diperoleh 
melalui post test. Dalam penelitian ini, soal tes berupa pilihan ganda dan uraian untuk mengetahui kemampuan pemahaman konsep matematika siswa. Observasi sebagai pengamatan tingkah laku pada situasi tertentu. Sedangkan teknik Observasi digunakan untuk memperoleh data kemampuan guru dalam mengelola Collaborative Learning Berbantuan Media Short Card Berbasis IT. Wawancara dilakukan untuk memperoleh informasi sebagai bahan kajian awal dengan tujuan menemukan permasalahan dan mengidentifikasi permasalahan sebelum dilakukan penelitian. Dokumentasi ini diperoleh dari pihak sekolah untuk memperoleh data-data yang sudah didokumentasikan oleh sekolah atau wali kelas sebagai data pendukung.

Adapun teknik analisis data pada penelitian ini adalah analisi ujicoba instrument, analisis pada data awal dan analisis data akhir. Sebelum instrumen tes digunakan untuk penelitian, dilakukan analisis uji coba. Analisis uji coba instrument terdiri dari daya beda, tingkat kesukaran, uji validitas dan reliabilitas. Sebelum peneliti melakukan penelitian, perlu adanya persyaratan sampel yang harus dianalisis, yaitu dengan menggunakan normalitas data dan uji homogenitas sampel. Data nilai yang digunakan dalam tahap ini adalah data awal berupa nilai harian yang sudah diperoleh. Data yang digunakan untuk uji normalitas pada tahap analisis data berasal dari nilai tes investigasi awal dari kelas penelitian. Dengan bantuan SPSS versi 16, dianalisis normalitas data yang digunakan untuk uji homogenitas pada tahap analisis data akhir berasal dari nilai tes dari kedua kelas penelitian. Uji kesamaan dua rata-rata diukur dengan uji-t hal ini bertujuan mengetahui apakah kedua kelas kesamaan rata-rata atau tidak sebagai uji data awal. Uji banding digunakan untuk membandingkan rataan kemampuan pemahaman konsep antara kelas pada collaborative learning dan kelas pada pembelajaran konvensional.

\section{HASIL DAN PEMBAHASAN}

Perbedaan kooperatif dan kolaboratif adalah pada kolaborasi pembelajaran lebih menekankan pada inisiatif mandiri yang terbentuk secara sendiri dan bukan rekayasa orang lain yang sengaja membentuk kerja sama. Pembelajaran kolaboratif merupakan pembelajaran kelompok yang terdiri dari beberapa siswa baik secara homogeny ataupun heterogen yang mana setiap individu dari anggota kelompok tersebut memiliki kemandirian yang akan mendukung dalam pembentukan suasana belajar kerjasama yang diikuti rasa ketergantungan dengan penuh tanggung jawa diantara anggota-anggota kelompoknya (Zamroni, 2000). Dalam Penerapan collaborative learning siswa SDN Karangroto 01 Semarang lebih dikondisikan pada suatu suasana yang dapat memacu kerjasama dan insisiatif siswa sehingga mereka lebih mandiri. Pembelajaran 
kolaboratif yang diterapkan ini disertai dengan media yang menarik yang dapat membuat pembelajaran matematika lebih bersifat konkret yakni media Short card. Adapun media short card yang digunakan dikolaborasikan dengan pemanfaatan IT sehingga lebih memotivasi siswa dan memacu minat belajar siswa.

Pada penelitian ini menerapkan pembelajaran kolaboratif yang memperhatikan beberapa hal. Diantaranya sebagaimana Kurikulum 2013 (K13) yang berbasis pada proyek. Maka pembelajaran kolaboratif yang diterapkan berorientasi proyek artinya dalam beberapa sesi siswa diberikan tugas dan lembar kerja untuk didiskusikan dan diselesaikan secara kelompok atau bersamasama bukan individual. Hal ini sesuai dengan prinsip Collaborative learning yang mana untuk kelas rendah bisa diterapkan dengan berpasangan dan untuk kelas tinggi diterapkan secara kelompok. Karena penelitian ini di kelas IV maka pembelajaran secara kelompok sebagai bagian dari Collaborative Learning.

Adapun kelompok kecil yang dibuat bersifat heterogen artinya dari campuran jenis kelamin, agama bahkan suku yang berbeda. Yang mana pembentukan ini secara tidak sengaja dalam hal ini peneliti menggunakan undian secara random dalam menentukan tiap kelompoknya. Pembelajaran kelompok kecil ini mempunyai dua fungsi yaitu untuk mengkolaborasi kerja individu dan mengkolaborasi untuk melompat dalam arti kolaborasi antara siswa-siswa, siswa-guru, siswa-materi pembelajaran.

Konsep pembelajaran hendaknya "melampaui batas dan melompat" yang dibentuk melalui kolaborasi sebagaimana yang diungkapkan oleh Sato (2007) bahwa mencapai target pembelajaran yang lebih tinggi dan lebih baik dapat menggunakan dengan pengajuan pertanyaan kepada siswa yang mana pertanyaan tersebut dapat memberikan kesempatan kepada siswa untuk belajar lebih mendalam seperti sebuah pertanyaan "Bagaimana saya bisa memecahkan masalah ini?". Pertanyaan ini dapat menciptakan keadaan yang membuat seorang siswa perlu bertanya kepada siswa lainnya. Disamping itu, menurut Sato (2007) masalah yang diberikan dalam pembelajaran haruslah lebih tinggi dari biasanya, karena semakin mudah masalah yang diberikan maka semakin jarang siswa yang bertanya kepada temmnya. Bagi siswa yang berada pada kelompok bawah dalam arti mempunyai kemampuan di bawah rata-rata kelas jika mereka tidak dapat memecahkan dan menyelesaiakn soal/masalah yang dianggap mudah untuk kelompok atau siswa lain maka mereka akan lebih cenderung untuk berusaha memecahkan masalah dan menghadapi kesulitannya tanpa bantuan orang lain. Sedangkan jika mereka gagal, mereka akan selalu tersisih dari yang lain, dan semakin tertinggal di belakang. Interaksi sosial sangat penting untuk membantu siswa memperoleh pemahaman melalui belajar dengan tingkat 
yang lebih tinggi dengan cara melampaui batas dan melompat dengan bantuan teman dan guru.

Adapun langkah-langkah pembelajaran kolaboratif meliputi tiga tahapan yaitu tahap persiapan atau perencanaan pembelajaran kolaboratif, tahap proses pembelajaran kolaboratif, dan tahap penilaian pembelajaran kolaboratif. Dari ketiga tahap pembelajaran kolaboratif tersebut, pada penelitian ini, hampir semua komponen pembalajaran kolaboratif digunakan pada pembelajaran.

Pada tahap persiapan guru membuat kelengkapan perangkat pembelajaran. faktor persiapan memiliki peranan yang penting dalam penyelenggaraan pembelajaran yang baik. Oleh karena itu, guru membuat perangkat pembelajaran kolaboratif yaitu RPP terlebih dahulu sebelum pembelajaran dimulai. Pembelajaran kolaboratif menekankan bagaimana siswa dapat bekerjasama, berinteraksi dan bertukar informasi melalui pembelajaran kelompok. Pada penelitian ini, guru sudah terlihat cukup baik dalam melakukan persiapan pembelajaran kolaboratif.

Pada tahap selanjutnya adalah
pelaksanaan kegiatan belajar mengajar
pembelajaran kolaboratif yang berdasar
perencanaan atau RPP yang sudah dibuat.

Adapun pada pelaksanaan Collaborative Learning guru menggunakan media short card yang berbasis IT. Hal ini bertujuan agar dalam pembelajaran matematika yang bersifat abstrak dapat disampaikan dengan baik menggunakan benda konkret yaitu pemanfaatan media. Sedangkan media short card dibuat berdasarkan IT agar siswa lebih tertarik pada pembelajaran mengingat perkembangan IT saat ini yang sudah sangat berkembang. Adapun langkah-langkah pelaksanaan pembelajaran dengan model Collaborative Learning berbantuan short card yang berbasis IT meliputi 1) guru melakukan presensi, 2) guru melakukan flashback atau mereview pelajaran sebelumnya, 3) guru melakukan apersepsi, 4) guru menyampaikan pentingnya pembelajaran materi yang akan disampaikan (motivasi), 5) siswa dibentuk kelompok 4-5 siswa secara heterogen, 6) siswa diberikan materi yang akan dipejari sebagai bahan diskusi, 7) guru menfasilitasi siswa membentuk suasana kolaboratif dalam pemahaman materi dengan berpedoman dengan unsur-unsur pembelajaran kolaboratif yaitu saling ketergantungan yang positif, interaksi langsung dengan siswa, pertanggungjawaban individu, ketrampilan kolaborasi dan keefektifan proses kelompok. 8) guru menggunakan media pembelajaran yakni media Short Card berbasis IT, 9) tiap kelompok mempresentasikan hasil disukusi, 10) guru menfasilitasi dalam melakukan konfirmasi pembelajaran, 11) guru mefasilitasi siswa untuk membuat kesimpulan materi pembelajaran, 12) guru merefleksi terhadap pembelajaran, dan 13) guru melakukan umpan balik dari pembelajaran. 
Inti dalam pembalajaran kolaboratif ini adalah para siswa belajar dalam kelompokkelompok kecil dan antar kolompok belajar dan saling membelajarkan untuk tujuan bersama. Proses penilaian pada Collaborative Learning berdasarkan pada hasil kerja kelompok. Selain itu, apapun dinamika yang terjadi dalam kelompok tersebut juga menjadi pertimbangan pada penilainnya. Secara umum penilaian pembelajaran kolaboratif tidak hanya dilakukan di akhir proses pembelajaran namun juga pada saat terjadinya interaksi antar siswa di dalam kegiatan pembelajaran.

\section{Pelaksanaan Collaborative Learning} dapat tejadi dengan baik dan maksimal jika didukung dari pihak guru, siswa, fasilitas kelas, dan dukungan dari pihak sekolah. Adapun pelaksanaan pembelajaran Collaboratif Learning di SDN Karangroto 01 kurang maksimal dikarenakan fasilitas yang kurang memadai. Media yang digunakan membutuhkan sarana IT yang mendukung seperti LCD Proyektor dan audio class. Namun, sarana tersebut tidak tersedia akhirnya peneliti menggunakan netbook sehingga media yang digunakan kurang optimal.

Pemahaman konsep sebagai kemampuan matematika yang masih dasar tentunya mempunyai peran penting dalam mencapai prestasi belajar matematika yang baik. Dengan karakteristik pembelajaran Colaboratif learning berbantuan Short Card Berbasis IT yang demikian akan efektif untuk meningkatkan kemampuan Pemahaman konsep siswa kelas IV SDN Karangroto 01.
Berdasarkan uji hipotesis I dihasilkan $\mathrm{t}_{\text {hitung }}=13,20, \quad \alpha=5 \%$ dengan $\mathrm{dk}=\left(n_{1}+n_{2}-2\right)=(48+48-2)=96$, $\mathrm{t}_{\text {tabel }}=1,99$. Karena $t_{\text {hitung }}>t_{\text {tabel }}(13,20>1,99)$ maka diterima $\mathrm{H}_{1}$ jadi rata-rata pemahaman konsep pada Collaborative Learning berbantuan Media Short Card berbasis IT $\geq$ rata-rata kemampuan pemahaman konsep matematika pada pembelajaran konvensional. Dengan demikian pemahaman konsep matematika siswa kelas IV SDN Karangroto 01 pada pembelajaran Collaboratif Learning berbantuan Short Card berbasis IT lebih baik daripada pemahaman konsep matematika pada pembelajaran konvensional.

Pemahaman konsep memiliki peranan yang sangat penting sebagai kemampuan dasar matematika agar presatasi belajar matematika maksimal. Adapun indikator pemahaman konsep adalah 1) Menghubungkan pengetahuan konseptual dan prosedural dengan mendefinisikan konsep baik melalui verbal maupun tertulis, 2) Mengidentifikasi contoh dan bukan contoh serta mampu membuatnya, 3) Menggunakan model dan fakta yang dapat menjelaskan pemikiran mereka, 4) Mengenal berbagai makna dan hubungan antara topik yang berbeda dalam matematika, 5) Mengubah suatu presentasi ke bentuk lain , 6) Membandingkan beberapa konsep dan membedakannya, dan 7) Menggunakan matematika dalam kehidupan sehari-hari mereka. 
Berdasarkan analisis tiap indikator pemahaman konsep antara kelas dengan pembelajaran collaborative learning dan pemahaman konsep pada pembelajaran konvesional diperoleh perbedaan yang sangat signifikan. Berikut grafik pemahaman konsep.

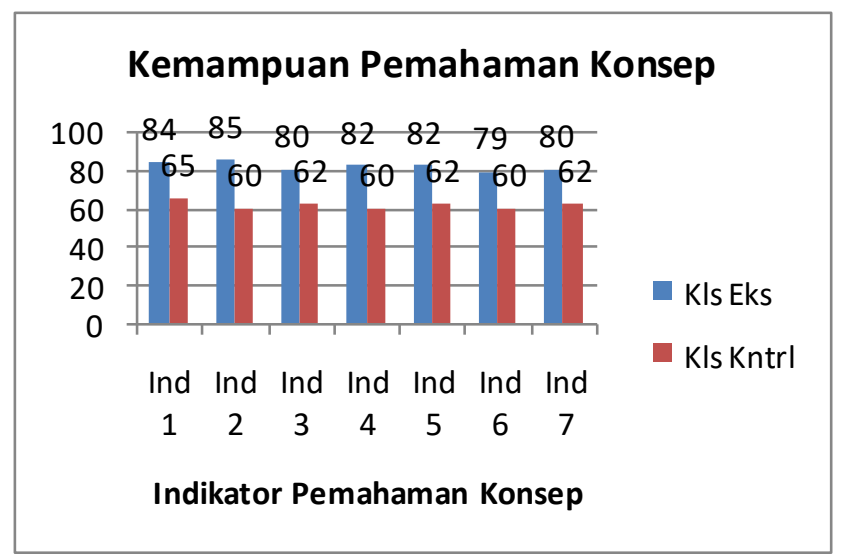

Gambar 1. Grafik pemahaman konsep

Berdasarkan grafik diatas terlihat jelas bahwa rata-rata prosentase pemahaman konsep pada kelas dengan pembelajaran Coolaborative learning lebih baik dibandingkan dengan pemahaman konsep yang dimiliki pada pembelajaran secara konvensional. Ini terjadi mungkin suasana pembelajaran Coolaborative learning dapat membuat siswa lebih semangat dalam pembelajaran mereka lebih difasilitasi dalam berdiskusi dan pembelajaran kelompok. Diskusi juga dilakukan pada pembelajaran konvensional namun tidak hidup artinya siswa yang aktif saja yang mendominasi pemblajaran. Pada pembelajaran Coolaborative learning suasana kolaboratif sudah sangat terbentuk seperti diskusi yang dilakukan merata semua siswa. Dan siswa yang kurang aktif bekerja sama dengan siswa yang aktif akhirnya mereka semua aktif. Artinya suasana kolaboratif terfasilitasi dengan baik. Guru sangat berperan penting sebagai fasilitator. Sebagai contoh, ketika siswa diberi tugas kelompok dalam menyelesaikan soal pemahaman konsep siswa saling belajar dan membelajarkan dengan siswa lainnya baik dalam satu kelompok ataupun dengan kelompok yang lain. Siswa juga dapat berkolaborasi dengan guru missal siswa menemukan beberapa kesulitan materi. Umpan dari guru sangat berpengaruh. Guru yang inovatif dan komunikatif dapat membuat dan mengantarkan pada suasana kelas yang lebih hidup.

Suasana belajar yang mendukung sangat diperlukan karena sesuai dengan teori yang yang dikemukakan oleh Vygotsky atau disebut teori Vygotsky yang menyatakan bahwa ZPD sebagai zona yang terdapat diantara tingkat perkembangan actual dan tingkat perkembangan potensial dapat ditingkatkan melalui suasana pembelajaran dan interaksi social guru dan siswa. Media pembelajaran juga mempunyai peranan yang sangat penting. Media short card berbasis IT yang digunakan mampu menarik minat dan motivasi belajar pada pembelajaran matematika. Siswa sangat antusias menyelesaikan soal-soal pendek tentang pemahaman konsep melui media tersebut. Pemilihan media sangat mempengaruhi dalam 
proses belajar mengajar. media berbasis IT dipilih karena pada era digital ini hamper semua anak tidak asing dengan media computer, laptop, smartphone, dll. Oleh karena itu, jka media tersebut digunakan dalam pembelajaran tentunya siswa semakin tertarik dan belajar seakan-akan seperti bermain. Hal inilah sebagai pendukung dalam pembelajaran. apalagi didukung juga dengan pembelajaran yang kolaboratif yang mana guru membuat suasana belajar menjadi kolaborasi antara siswa dengan guru antara sisa aktif dengan pasif antara siswa cerdas dengan yang kurang dan seterusnya sehingga kerjasama terbentuk dengan apik dan dapat mamacu kemampuan pemahaman konsep menjadi lebih baik.

\section{PENUTUP}

Pembelajaran Coolaborative Learning berbantuan Short Card berbasis IT merupakan pembelajaran yang menerapkan unsur-unsur kolaboratif pada pembejalarannya yang mempunyai tiga tahap yaitu perencanaan, pelaksanaan dan penilaian. Penggunaan media Short Card berbasis IT dalam pembelajaran kolaboratif dapat mendukung pembelajaran sehingga lebih menarik siswa dan mendukung interaksi siswa dalam pembelajaran. Kemampuan pemahaman konsep pada Pembelajaran Coolaborative Learning berbantuan Short Card berbasis IT lebih baik dibandingkan dengan pemahaman konsep pada pembelajaran secara konvensional.

\section{UCAPAN TERIMAKASIH}

Ucapan terima kasih ditujukan kepada FKIP UNISSULA yang telah memberikan dana untuk penelitian ini dan Kepala SDN Karangroto 01 Semarang yang telah memberikan ijin tempat penelitian serta semua pihak yang terkait dalam pelaksanaan penelitian ini.

\section{DAFTARPUSTAKA}

Bafadal,I. 2003. Manajemen Peningkatan Mutu Sekolah Dasar Dari Sentralisasi menuju Desentralisasi. Jakarta: Bumi Aksara

Herlanti,Y. 2011.Pembelajaran Kolaboratif. Tersedia online di yherlanti.wordpress.com Diakses pada tanggal 20 Maret 2017

Sato, M. 2007. Tantangan yang harus dihadapi Sekolah, makalah dalam Bacaan Rujukan untuk Lesson StudyBerdasarkan pengalaman Jepang dan IMSTEP. Jakarta: Sisttems

Sugiyono. 2015. Metode Penelitian Pendidikan Pendekatan Kuantitatif, Kualitatif, dan $R \& D$. Bandung: Alfabeta Tribunews. 2011. Kasus Ibu Siami Bukti Pelaksanaan UN Terjadi Kecurangan. www.tribunnews.com. Diakses pada tanggal 1 April 2017.

Zamroni. 2000. Pembelajaran kolaboratif. Jakarta: Gramedia 
